DOI

\title{
МІКРОБІОЛОГІЧНЕ ДОСЛІДЖЕННЯ ВМІСТУ КОРЕНЕВИХ КАНАЛІВ ЗУБІВ ІЗ ХРОНІЧНИМ АПІКАЛЬНИМ ПЕРІОДОНТИТОМ ПРИ ВИКОРИСТАННІ РОЗЧИНУ ПОВІДОН-ЙОДУ В ЯКОСТІ ФОТОСЕНСИБІЛІЗАТОРА
}

\section{Харківський національний медичний університет}

๑Н. О. Жданова

РЕЗЮМЕ. У статті представлені результати дослідження мікрофлори кореневих каналів зубів при лікуванні хронічного апікального періодонтиту. Пацієнти були поділені на 2 групи: основну і контрольну. Пацієнтам основної групи проводили лікування кореневих каналів методом фотоактивованої дезінфекції з використанням повідон-йоду в якості хроматофора. Хворі контрольної групи були проліковані за стандартною методикою. Аналіз результатів мікробіологічного дослідження вмісту кореневих каналів після створення ендодонтичного доступу до інструментальної та медикаментозної обробки у всіх групах показав велику різноманітність, кількість ідентифікованих культур припадає на долю грампозитивної мікрофлори.

КЛЮчОВІ СЛОВА: хронічний апікальний періодонтит, фотоактивована дезінфекція, повідон-йод, мікрофлора кореневих каналів.

Вступ. Частота захворювань пульпи і періодонта у дітей і дорослих не має тенденції до зниження. При лікуванні хронічного періодонтиту спостерігається великий відсоток невдач, як у найближчі, так і у віддалені терміни. Найбільшу небезпеку для організму людини становлять деструктивні форми хронічного періодонтиту. Хронічні вогнища запалення в ділянці верхівки кореня зуба можуть бути причиною одонтогенних запальних процесів щелепно-лицьової ділянки та здатні порушувати імунологічний статус організму (Шумський А. В., 2003; Каплан Д. Ж., 2006; Мітронін О. В., 2007; Халсмен М., 2009).

Бактерії, які присутні в кореневих каналах, $\epsilon$ стійким джерелом інфікування по відношенню до захисних механізмів організму і антисептиків, які застосовуються під час лікування періодонтиту.

На сьогоднішній час введено застосування методу бактеріотоксичної терапії - фотоактивованої дезінфекції (Рісованая О. Н., 2006; Бургонський В. Г., 2012). Принцип його роботи грунту$є$ єься на тому, що молекули фотосенсибілізатора прикріплюються до мембрани бактерії. Опромінення світлом з певною довжиною хвилі, відповідної піку поглинання фотосенсибілізатора, приводить до утворення атомарного кисню, який руйнує стінки бактеріальних, грибкових і вірусних клітин (Бонсор Дж., 2007). Існує безліч видів фотосенсибілізаторів, які найширше використовуються в стоматологічній практиці і $\epsilon$ ефективними в боротьбі з цілою низкою грампозитивних та грамнегативних бактерій.

У літературі $\epsilon$ дані про можливість застосування повідон-йоду у якості хроматофору при фотоактивованій дезінфекції. У сучасній стоматології існує велика кількість досліджень, які доводять ефективність повідон-йоду у пародонтологіï (Simona Lomanno, Delfina Pacifico, Leonzio
Fortunato, Roberto Del Giudice, 2015) та при лікуванні карієсу (Maryam S. A., 2004; Herdiyati Y., 2015). Можливість застосування повідон-йоду в ендодонтії для антисептичної обробки кореневих каналів $\epsilon$ недостатньо вивченою.

Мета дослідження: визначення мікробного пейзажу кореневих каналів зубів при лікуванні хронічного апікального періодонтиту методом фотоактивованої дезінфекції з використанням повідон-йоду в якості фотосенсибілізатора.

Матеріал і методи дослідження. Дослідження було проведене на базі Університетського стоматологічного центру Харківського національного медичного університету. Було обстежено та проліковано 35 осіб, у яких був діагностований хронічний апікальний періодонтит за класифікацією MKX-10.

Ендодонтичну обробку проводили на повну робочу довжину кореневих каналів. Для очищення кореневих каналів застосовували комбінований метод хімічного і механічного впливу, що передбачає використання ручних інструментів, машинних нікель-титанових інструментів, ендодонтичного мотора, 3 \% розчину гіпохлориту натрію, гелю та рідини ЕДТА 17 \% (етилендіамінтетраоцтової кислоти). Постійну обтурацію кореневого каналу проводили методом холодної латеральної конденсації гутаперчі, застосовуючи силер на основі епоксидних смол та гутаперчевих штифтів.

Залежно від обраного методу лікування хронічного апікального періодонтиту пацієнтів поділили на дві групи: основну та контрольну.

Основна група включала 16 осіб. Окрім ендодонтичної обробки кореневих каналів, замість стандартного протоколу іригації, до плану лікування хронічного апікального періодонтиту була застосована фотоактивована дезінфекція (ФАД) кореневих каналів, після якої проводили постійну 
Огляди літератури, оригінальні дослідження, погляд на проблему

обтурацію у одне відвідування. Фотоактивовану дезінфекцію кореневих каналів проводили із застосуванням фотосенсибілізатора - $10 \%$ розчину повідон-йоду. У якості джерела випромінювання був використаний лазерний терапевтичний апарат «Лика-Терапевт М» в інфрачервоному оптичному діапазоні з довжиною хвилі 810 нм. Після завершення стандартної ендодонтичної обробки у кореневий канал за допомогою ендодонтичного шприца та канюлі вводили фотосенсибілізувальний розчин, який попередньо розводили у дистильованій воді 1:10. Розчин залишали in situ протягом 60 секунд, потім у канал вводили випромінювач і проводили активацію протягом 120 секунд. Наступним етапом лікування було висушування кореневих каналів паперовими пінами, стандартна постійна обтурція та контрольна рентгенограма для оцінки якості пломбування.

Контрольна група складалась із 19 осіб. Протокол лікування був одноетапним та включав у себе ендодонтичну обробку кореневих каналів із стандартним протоколом іригації 3 \% розчином гіпохлориту натрію і 17 \% розчином ЕДТА та постійну обтурацію.

Мікробіологічні дослідження проводили на базі кафедри клінічної імунології та мікробіології Харківської академії післядипломної освіти згідно з діючими нормативними документами за загальноприйнятими методиками. Забір вмісту кореневих каналів проводили паперовим стерильним штифтом 15 або 20 розміру на транспортне стерильне середовище Еймса 10 мл. Матеріал протягом доби доставляли до мікробіологічної лабораторії для кількісного бактеріологічного дослідження із застосуванням анаеробної техніки культивування. Кількісний посів матеріалу проводили секреторним методом за Голдом (1965р.). Виділення чистих культур анаеробних мікроорганізмів і подальшу їх ідентифікацію проводили, використовуючи поживні середовища, призначені для їх культивування.

Для виявлення в досліджуваному матеріалі аеробної або факультативно анаеробної мікрофлори проводили посів на скошений кров'яний агар і цукровий агар. Посіви інкубували протягом 24-72 год у термостаті. На другому етапі проводили макро- і мікроскопічне дослідження колоній, приготування мазка і забарвлення препарату за Грамом. Виділення чистих культур проводять загальноприйнятими заходами бактеріологічного дослідження. На підставі отриманих даних проводили ідентифікацію мікроорганізмів за бінарною номенклатурою з визначенням кількості виділеного штаму в матеріалі.

В усіх групах, які брали участь у дослідженні, забір матеріалу та культуральне дослідження проводили двічі: перед початком лікування та перед постійною обтурацією після проведення всіх запланованих лікувальних маніпуляцій.

Результати й обговорення. Аналіз результатів мікробіологічного дослідження вмісту кореневих каналів після створення ендодонтичного доступу до інструментальної та медикаментозної обробки у всіх групах показав велику різноманітність: видовий склад представлений 13 видами бактерій та одним родом дріжджоподібних грибів (табл. 1).

Таблиця 1. Видовий склад мікрофлори кореневих каналів зубів з хронічним апікальним періодонтитом

\begin{tabular}{|c|c|}
\hline Вид мікроорганізму & Частота знаходження, \% \\
\hline Enterococcus faecalis & 56,2 \\
\hline Staphylococcus epidermidis & 43,9 \\
\hline Candida albicans & 32,8 \\
\hline Pseudomonas aeruginosa & 18,9 \\
\hline Escherichia coli & 25,2 \\
\hline Streptococcus & 22,5 \\
\hline - sanguis & 9,6 \\
\hline - mutans & 8,2 \\
\hline - intermedius & 1,1 \\
\hline - mitis & 3,6 \\
\hline Peptostreptococcus spp. & 6,2 \\
\hline Actinomyces spp. & 4,7 \\
\hline Lactobacillus spp. & 8,5 \\
\hline
\end{tabular}

У пацієнтів основної групи були отримані результати, що свідчать про виражену антимікробну дію запропонованого методу ФАД (табл. 2). Після проведення бактеріотоксичної терапії 10 \% розчином повідон-йоду не було ідентифіковано мікроб- них асоціацій Enterococcus faecalis, Escherichia coli, Peptostreptococcus spp, Actinomyces spp та Lactobacillus spp. Концентрація інших мікроорганізмів достовірно $(p<0,05)$ знизилась, порівняно 3 вихідним рівнем. 
Огляди літератури, оригінальні дослідження, погляд на проблему

Таблиця 2. Характеристика мікробного пейзажу кореневих каналів зубів у основній групі

\begin{tabular}{|c|c|c|c|c|}
\hline Вид мікроорганізму & $\begin{array}{c}\text { Частота } \\
\text { знаходження до } \\
\text { лікування, \% }\end{array}$ & 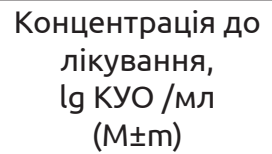 & $\begin{array}{c}\text { Частота } \\
\text { знаходження } \\
\text { перед постійною } \\
\text { обтурацією, \% }\end{array}$ & $\begin{array}{c}\text { Концентрація перед } \\
\text { постійною обтурацією, } \\
\text { lg КУО /мл } \\
(\mathrm{M} \pm \mathrm{m})\end{array}$ \\
\hline Enterococcus faecalis & 59,6 & $7,4 \pm 1,1$ & 0 & 0 \\
\hline Staphylococcus epidermidis & 46,3 & $5,9 \pm 0,8$ & $32,5 *$ & $1,1 \pm 0,4^{*}$ \\
\hline Candida albicans & 32,5 & $6,2 \pm 0,9$ & $18,0 *$ & $1,2 \pm 0,3 *$ \\
\hline Pseudomonas aeruginosa & 18,5 & $6,9 \pm 0,7$ & 15,0 & $1,2 \pm 0,4^{*}$ \\
\hline Escherichia coli & 25,5 & $6,1 \pm 1,0$ & 0 & 0 \\
\hline Streptococcus spp. & 23,7 & $5,9 \pm 0,8$ & $17,6^{*}$ & $1,3 \pm 0,5^{*}$ \\
\hline Peptostreptococcus spp. & 6,0 & $5,6 \pm 0,6$ & 0 & 0 \\
\hline Actinomyces spp. & 4,3 & $4,3 \pm 0,9$ & 0 & 0 \\
\hline Lactobacillus spp. & 8,5 & $4,4 \pm 0,7$ & 0 & 0 \\
\hline
\end{tabular}

Примітка. * - статистично значущі розбіжності у зіставленні даних до та після лікування, $p<0,05$.

У групі контролю щільність ценозів мікроорганізмів достовірно знизилась $(p<0,05)$, але залишалась вищою, порівняно з основною групою (табл. 3). Статистично значущої розбіжності між вихідними рівнями концентрації та частотою знаходження мікроорганізмів у основній групі відносно контрольної виявлено не було ( $>>0,05)$. Стандартна ендодонтична обробка показала 100 \% ефективність відносно бактерій роду Peptostreptococcus та Actinomyces, які не були ідентифіковані після медикаментозної обробки кореневих каналів у жодного з пацієнтів.

Таблиця 3. Характеристика мікробного пейзажу кореневих каналів зубів у контрольній групі

\begin{tabular}{|c|c|c|c|c|}
\hline Вид мікроорганізму & $\begin{array}{c}\text { Частота } \\
\text { знаходження до } \\
\text { лікування, \% }\end{array}$ & $\begin{array}{c}\text { Концентрація до } \\
\text { лікування, } \\
\text { lg КУО /мл } \\
(\mathrm{M} \pm \mathrm{m})\end{array}$ & $\begin{array}{c}\text { Частота } \\
\text { знаходження } \\
\text { перед постійною } \\
\text { обтурацією, \% } \\
\end{array}$ & $\begin{array}{c}\text { Концентрація перед } \\
\text { постійною обтурацією, } \\
\text { lg КУО /мл } \\
(\mathrm{M} \pm \mathrm{m}) \\
\end{array}$ \\
\hline Enterococcus faecalis & 56,4 & $7,9 \pm 0,9$ & 41,2 & $3,2 \pm 0,6^{*}$ \\
\hline Staphylococcus epidermidis & 41,5 & $5,0 \pm 0,8$ & 35,4 & $3,3 \pm 0,7$ \\
\hline Candida albicans & 34,0 & $6,9 \pm 1,1$ & 28,5 & $4,3 \pm 0,9 *$ \\
\hline Pseudomonas aeruginosa & 17,5 & $6,5 \pm 0,7$ & 16,0 & $5,2 \pm 0,9 *$ \\
\hline Escherichia coli & 25,0 & $6,9 \pm 0,29$ & 18,6 & $4,0 \pm 0,7$ * \\
\hline Streptococcus spp. & 23,5 & $5,6 \pm 0,7$ & 17,2 & $4,1 \pm 0,4$ \\
\hline Peptostreptococcus spp. & 6,0 & $5,9 \pm 0,9$ & 0 & 0 \\
\hline Actinomyces spp. & 5,5 & $4,1 \pm 0,3$ & 0 & 0 \\
\hline Lactobacillus spp. & 8,6 & $4,3 \pm 0,6$ & 5,2 & $1,2 \pm 0,3 *$ \\
\hline
\end{tabular}

Примітка. * - статистично значущі розбіжності у зіставленні даних до та після лікування, p<0,05.

Висновки. 1.У кореневих каналах із хронічним апікальним періодонтитом найчастіше ідентифікували Enterococcus faecalis (56,2 \%), Staphylococcus epidermidis (43,9\%), Candida albicans (32,8\%), Pseudomonas aeruginosa (18,9\%) та Escherichia coli $(25,2 \%)$.

2. Найменш стійкими відносно проведеної терапії штамами бактерій виявились Enterococcus faecalis, бактерії роду Peptostreptococcus, Actinomyces та Lactobacillus. Enterococcus faecalis, Peptostreptococcus та Lactobacillus перед тимчасовою обтурацією були виявлені лише у контрольній групі у незначній концентрації. Бактерії роду Actinomyces не були виявлені після лікування в жодній з груп.

3. Фотоактивована дезінфекція кореневих каналів з використанням повідон-йоду в якості хроматофору є ефективним методом у лікуванні хронічного апікального періодонтиту, що знижує концентрацію мікробних ценозів до етіологічно не значущої концентрації.

Перспективи подальших досліджень. Продовження досліджень рентгенологічних та клінічних аспектів перебігу хронічного апікального періодонтиту з метою підвищення якості та оптимізації лікування. 
Огляди літератури, оригінальні дослідження, погляд на проблему

\section{ЛІТЕРАТУРА}

1. О распространенности верхушечного периодонтита / Н. Б. Данилова, А. С. Иванов, Р. К. Дроздова, Н. В. Костюкова // Современные вопросы стоматологии. - Ижевск, 2000. - С. 180-183.

2. Этиопатогенетические факторы развития воспалительных заболеваний периодонта / В. Н. Царев, Р. В. Ушаков, Е. Я. Ясникова, А. В. Митронин // Стоматолог. - 2005. - № 6. - С. 16-23.

3. Боровский Е. В. Состояние эндодонтии в цифрах и фактах / Е. В. Боровский // Клиническая стоматология. - 2003. - № 1. - С. 38-40.

4. Соловьева Ж. В. Анализ микрофлоры корневого канала при эндодонтической патологии по результатам первичного обследования пациентов / Ж. В. Соловьева // Международный журнал прикладных и фундаментальных исследований. - 2014. - № 2. - С. 168-172.

5. Особенности микрофлоры корневых каналов при разных формах периодонтита / А. С. Носик, С. Д. Арутюнов, Э. Г. Маргарян, Т. В. Царева // Дентал-инфо. - 2007. C. 192-193.

6. Альтернативный режим дезинфекции корневых каналов/С. Дж. Бонсор, Р. Ничол, Т. М. С. Райд, Г. Дж. Пирсон // Клиническая стоматология. - 2007. - № 2. C. 6-12.

7. Рисованная О. Н. Исследование бактериотоксического действия светотерапии на патогенную флору полости рта / О. Н. Рисованная // Российский стоматологический журнал. - 2003. - № 6. - С. 17-20.
8. Ніколішин А. К. Антибактеріальна активність світлових променів і фотосенсибілізаторів / А. К. Ніколішин, Ю. В. Сідаш, В.І.Федорченко // Український стоматологічний альманах. - 2010. - Т. 3, № 2. - С. 35-39.

9. Effect of photoactivated disinfection with a light-emitting diode on bacterial species and biofilms associated with periodontitis and peri -implantitis / E. Sigrun, M. Giedre, S. Nietzsche [et al.] // Photodiagnosis and Photodynamic Therapy. - 2013. - Vol. 10, № 2. P. 156-167.

10. Fleischer $\mathbf{W}$. Povidone-iodine in antisepsis-state of the art /W. Fleischer, K. Reimer // Dermatology. 1997. Vol. 195, № 2. - P. 3-9.

11. Molecular effects of povidone-iodine on relevant microorganisms: An electron-microscopic and biochemical study / Shreier H. Erdos, K. Reimer, B. Konig, W. Konig [et al.] // Dermatology 1997. - Vol. 195, № 2. - P. 111-117.

12. Stop Caries with Povidone lodine / Y. Herdiyati, E. Riyanti, D. Prastuti, P. Andisetyanto // International Journal of Science and Research. -20.

13. Maryam S. A. Effect of Povidone-iodine on Streptococcus Mutans in Children With Extensive Dental Caries / S. A. Maryam, M. Rosamund, S. Tonya Benton [et al.] // Pediatric Dentistry. - 2004. - Vol. 26, № 1. - P. 5-10.

14. Talebi M. Microbiological efficacy of photodynamic therapy as an adjunct to non-surgical periodontal treatment: a clinical trial / M. Talebi // Lasers in medical science. - 2016. - Vol. 7, № 2. - P. 126-130.

\section{MICROBIOLOGICAL RESEARCH OF ROOT CANALS CONTENT WITH CHRONIC APICAL PERIODONTITIS USING POVIDONE-IODINE SOLUTION AS A PHOTOSENSITIZER}

@N. O. Zhdanova

\section{Kharkiv Medical National University}

SUMMARY. The article is devoted to the results of the study of root canals microflora in the treatment of chronic apical periodontitis. Patients were divided into 2 groups: basic and control. Patients of the main group were treated by root canal photo-activated disinfection using povidone-iodine as a chromatophore. Patients in the control group were treated by the standard method. Analysis of microbiological research content of root canals after endodontic treatment and access to drug treatment in all groups showed a huge number of gram-positive microorganisms.

KEY WORDS: chronic apical periodontitis, photo-activated disinfection, povidone-iodine, microflora of root canals. 